\title{
Perioperative management of massive pulmonary hemorrhage after pulmonary endarterectomy
}

\author{
Pulmoner endarterektomi sonrası masif akciğer kanamasının perioperatif tedavisi
}

\author{
Şehnaz Olgun Yıldızeli ${ }^{1}$ ', Atakan Erkılınç $\mathbb{D}^{2}$, Mehmed Yanartaş $\mathbb{B}^{3}$, Serpil Taş $\circledast^{3}$, \\ Hasan Sunar $\mathbb{1}^{3}$, Emre Gürcü ${ }^{2}$, Bedrettin Yıldızeli ${ }^{4}{ }^{4}$ \\ Institution where the research was done: \\ University of Health Sciences, Kartal Koşuyolu Training and Research Hospital, İstanbul, Turkey
}

Author Affiliations:

'Department of Chest Diseases and Intensive Care, Medicine Faculty of Marmara University, ìstanbul, Turkey 2Department of Anesthesiology and Reanimation, University of Health Sciences, Kartal Koşuyolu Training and Research Hospital, istanbul, Turkey ${ }^{3}$ Department of Cardiovascular Surgery, University of Health Sciences, Kartal Koşuyolu Training and Research Hospital, istanbul, Turkey ${ }^{4}$ Department of Thoracic Surgery, Medicine Faculty of Marmara University, Istanbul, Turkey

\begin{abstract}
Background: This study aims to evaluate our approaches and outcomes in patients who developed hemoptysis following pulmonary endarterectomy.

Methods: Pulmonary endarterectomy was performed in 460 patients at Kartal Koşuyolu Training and Research Hospital between March 2011 and September 2017. Clinical characteristics, perioperative management and postoperative outcomes of 10 patients $(2.1 \%)$ ( 4 males, 6 females; mean age $48.3 \pm 16.5$ years; range 21 to 76 years) with massive pulmonary hemorrhage following pulmonary endarterectomy were evaluated.

Results: Mean period of diagnosis for chronic thromboembolic pulmonary hypertension was $17 \pm 13.6$ months. All patients were New York Heart Association functional class II $(n=2)$, III $(n=5)$ or IV $(n=3)$. For the treatment of massive pulmonary hemorrhage, intraoperative extracorporeal membrane oxygenation was used in six patients $(60 \%)$, while conservative treatments were used in four patients $(40 \%)$. In-hospital mortality rate was $50 \%(n=5)$; the causes for mortality were septic shock in two patients, multiple organ failure in two patients and intracranial hemorrhage in one patient. Survival was achieved in two patients on extracorporeal membrane oxygenation and three patients receiving conservative treatment. Functional and hemodynamic improvement was observed in all surviving patients.
\end{abstract}

Conclusion: Despite the relatively low incidence of massive pulmonary hemorrhage after pulmonary endarterectomy, it is a potentially fatal complication. Our approach focuses on early diagnosis with a multidisciplinary team and management with bronchoscopy, bronchial blockers and use of extracorporeal membrane oxygenation. The choice of treatment depends on the site and origin of the hemorrhage, the availability of equipment and expertise, and the potential short- and long-term advantages and disadvantages.

Keywords: Chronic thromboembolic pulmonary hypertension; extracorporeal membrane oxygenation; massive pulmonary hemorrhage; pulmonary endarterectomy.
$\ddot{O} Z$

Amaç: Bu çalışmada pulmoner endarterektomi sonrası hemoptizi gelişen hastalarımıza yaklaşım ve sonuçlarımız değerlendirildi.

Çalışma planı: Mart 2011 ve Eylül 2017 tarihleri arasında 460 hastaya Kartal Koşuyolu Eğitim ve Araștırma Hastanesi'nde pulmoner endarterektomi uyguland. Pulmoner endarterektomi sonrası masif akciğer kanamalı 10 hastanın (\%2.1) (4 erkek, 6 kadın; ort. yaş $48.3 \pm 16.5$ yıl; dağılım 21-76 yıl) klinik özellikleri, perioperatif tedavi ve ameliyat sonrası sonuçları değerlendirildi.

Bulgular: Kronik tromboembolik pulmoner hipertansiyona ortalama tanı konulma süresi $17 \pm 13.6$ ay idi. Tüm hastalar New York Kalp Cemiyeti fonksiyonel sinıf II $(n=2)$, III $(n=5)$ ya da IV $(n=3)$ idi. Masif akciğer kanaması tedavisinde altı hastada (\%60) ameliyat sırası ekstrakorporeal membran oksijenasyonu, dört hastada (\%40) ise konservatif tedaviler kullanıldı. Hastane mortalitesi oranı \%50 ( $\mathrm{n}=5)$ idi; mortalite nedeni iki hastada septik şok, iki hastada çoklu organ yetmezliği ve bir hastada intrakranial kanama idi. Ekstrakorporeal membran oksijenasyonundaki iki hasta ve konservatif tedavi gören üç hastada sağkalım sağlandı. Sağ kalan tüm hastalarda fonksiyonel ve hemodinamik iyileşme gözlendi.

Sonuç: Pulmoner endarterektomi sonrası masif akciğer kanaması insidansı göreceli düşük olmakla beraber, bu potansiyel olarak ölümcül bir komplikasyondur. Yaklaşımımız multidisipliner bir ekip ile erken tanı ve bronkoskopi, bronşiyal blokerler ve ekstrakorporeal membran oksijenasyonu kullanımı ile tedaviye odaklanmaktadır. Tedavi tercihi kanamanın yer ve kaynağına, eldeki araç ve deneyime ve olası kısa ve uzun dönem avantaj ve dezavantajlara bağlıdır.

Anahtar sözcükler: Kronik tromboembolik pulmoner hipertansiyon; ekstrakorporeal membran oksijenasyonu; masif akciğer kanaması; pulmoner endarterektomi.

Received: October 10, 2017 Accepted: December 12, 2017

Correspondence: Bedrettin Yıldızeli, MD. Marmara Üniversitesi Tıp Fakültesi, Göğüs Cerrahisi Anabilim Dalı, 34854 Maltepe, Istanbul, Turkey. Tel: +90 216 - 4452525 e-mail: byildizeli@marmara.edu.tr 
Pulmonary endarterectomy (PEA) is the only curative treatment for chronic thromboembolic pulmonary hypertension (CTEPH). The success of PEA depends upon complete endarterectomy of the intima, chronic organized thromboembolic material, and part of the media of the affected pulmonary arteries (PAs) ${ }^{[1]}$ Despite the technically challenging nature and the increasing frequency of this surgery, pulmonary hemorrhage remains a rare occurrence after PEA, with a reported incidence of 0.5 to $2 \%{ }^{[2,3]}$ While the exact mechanism of pulmonary hemorrhage after PEA is often unknown, surgical trauma resulting in the disruption of the arterial adventitia and/or increased capillary permeability following restored perfusion as a form of severe acute lung injury are both plausible mechanisms. ${ }^{[4]}$ Initial management focuses on the maintenance of hemodynamics and gas exchange. Since the beginning of the implementation of PEA in our center ${ }^{[5]}$ patient referrals have increased substantially over the years, and we have become more experienced in the procedure and its complications. We have previously published two case reports about the management of pulmonary hemorrhage following PEA. ${ }^{[6,7]}$ In this study, we aimed to evaluate our approaches and outcomes in patients who developed hemoptysis following PEA.

\section{PATIENTS AND METHODS}

A total of 460 consecutive patients underwent PEA at Kartal Koşuyolu Training and Research Hospital between March 2011 and September 2017. The medical records of 10 patients (2.1\%) (4 males, 6 females; mean age $48.3 \pm 16.5$ years; range 21 to 76 years) with massive pulmonary hemorrhage following surgery were reviewed to evaluate the clinical characteristics, perioperative management and the postoperative outcomes. All data were collected prospectively and entered into a database. Demographic features such as age, gender, age of onset, duration of disease and pulmonary function tests, complications, in-hospital mortality, and length of hospital stay were recorded. The diagnosis of CTEPH was established by sixminute walking test, while the presence of mismatched perfusion defects on the ventilation perfusion scan was associated with evidence of pulmonary hypertension on transthoracic echocardiogram, despite adequate anticoagulation for at least three months. Diagnosis and cardiopulmonary hemodynamic characteristics were determined by computed tomography pulmonary angiography (CTPA) and right heart catheterization (RHC). Our indications for PEA were as follows: New York Heart Association functional class greater than II and absence of significant comorbidities and CTPA or scintigraphic evidence of obstruction of the pulmonary arterial tree. Our technique of PEA was previously described. ${ }^{[5]}$ Shortly, the operation was performed on deep hypothermia $\left(20^{\circ} \mathrm{C}\right)$ for both lungs under complete circulatory arrest. A true endarterectomy was accomplished and, when it was completed on both sides, circulation with warming was restarted (Figure 1). Weaning from cardiopulmonary bypass (CPB) was performed with care. Any hemorrhage that was noted in the endotracheal tube upon separation from CPB was defined as massive pulmonary hemorrhage. Our algorithm for treatment of hemoptysis is presented in Figure 2. Initial fiberoptic bronchoscopy (FOB) was performed to identify the color and location of the hemorrhage. Frothy

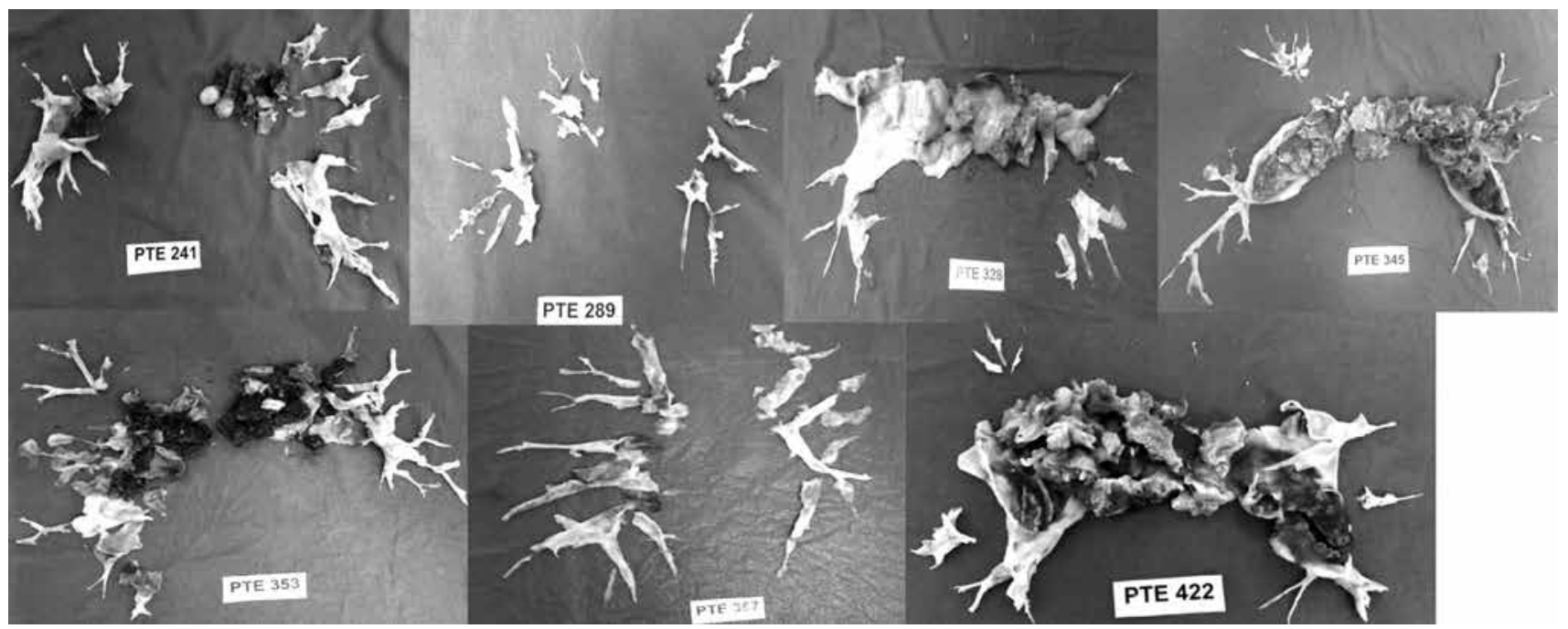

Figure 1. Surgical specimens of all cases except case 1, 3 and 5. ${ }^{[6,7,9]}$ 


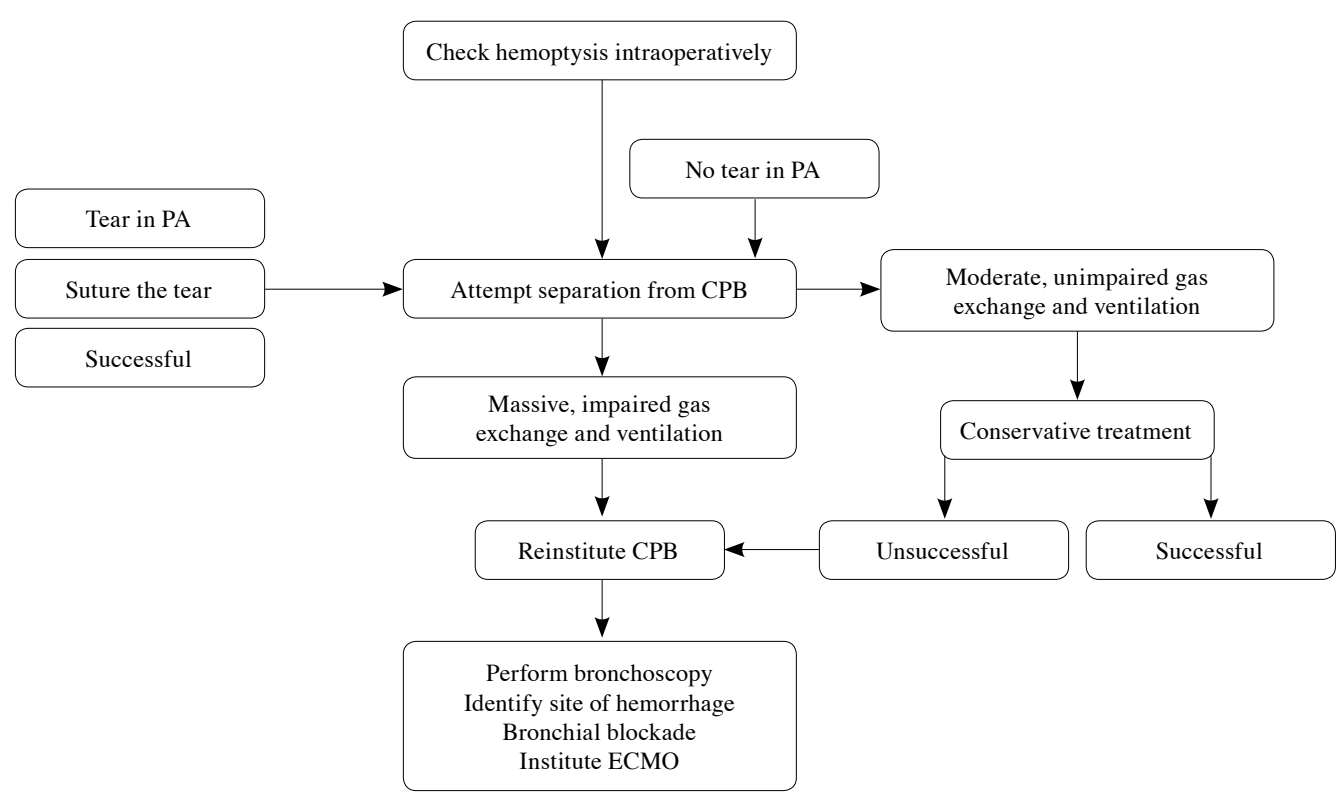

Figure 2. A general algorithm for treatment of hemoptysis.

PA: Pulmonary artery; CPB: Cardiopulmonary bypass; ECMO: Extracorporeal membrane oxygenation.

and bright red hemorrhage suggested reperfusion lung injury or pulmonary edema and conservative treatment with phenylephrine $10 \mathrm{mg}$ and vasopressin $20 \mathrm{U}$ diluted to $10 \mathrm{~mL}$ with normal saline via the endotracheal tube and hyperventilation (volume control mode, respiratory rate 15 breaths/minute, tidal volume $500 \mathrm{~mL}$, fraction of inspired oxygen $100 \%$, and positive end-expiratory pressure [PEEP] 15 centimeters of water $\left[\mathrm{cmH}_{2} \mathrm{O}\right]$ ) was performed. Heparin was reversed with intravenous protamine (350 mg) and coagulopathies were corrected with fresh frozen plasma and platelets. On the other hand, if color of the hemorrhage was dark red, suggestive of tear in PA, the bronchus in which the hemorrhage was observed was occluded with a bronchial blocker and extracorporeal membrane oxygenation (ECMO) was instituted because of hypoxia and hemodynamic instability. The bronchial blocker was deflated and removed 24 or 48 hours after the surgery if there was no evidence of ongoing hemorrhage. When no active hemorrhage was confirmed and oxygenation/ ventilation had improved on two-lung ventilation, ECMO was weaned.

In order to detect any hemorrhage point intraoperatively, we adopted the technique described by Morsolini et al. ${ }^{[8]}$ After endarterectomy was completed in one lung, the main PA was filled with saline. At this time, gentle positive pressure was delivered to the airway through the anesthetic circuit, and bubbling was checked in the PA lumen. The area was then flooded with saline solution and rechecked with hand ventilation. If bubbling was visualized, under circulatory arrest, that particular branch of the PA was closed with an $6 / 0$ pronene suture $\left(\right.$ PROLENE $^{\circledR}$ Polypropylene Suture, Ethicon, CA, USA). Operative mortality was defined as death in hospital or within 30 days of surgery. Length of in-hospital and intensive care unit (ICU) stay were noted. The study protocol was approved by the Kartal Koşuyolu Training and Research Hospital Ethics Committee. A written informed consent was obtained from each patient. The study was conducted in accordance with the principles of the Declaration of Helsinki.

\section{Statistical analysis}

All data were collected, tabulated and statistically analyzed. Numerical variables were presented as mean and standard deviation. Continuous random variables were presented as median and range (maximum-minimum values). Statistical analyses were carried out using SPSS for Windows version 13.0 software (SPSS Inc., Chicago, IL, USA).

\section{RESULTS}

The pre- and intraoperative characteristics of patients are presented in Table 1. Eight patients presented with a history of pulmonary embolism, while two patients had a history of deep venous thromboembolism. Exerciseinduced dyspnea was the presenting symptom in seven patients. One patient had Behçet's disease, ${ }^{[9]}$ one had 
Table 1. Demographic and clinical characteristics of patients

\begin{tabular}{|c|c|c|c|c|c|}
\hline Characteristics & $\mathrm{n}$ & $\%$ & Mean \pm SD & Range & Min-Max \\
\hline Age (year) & & & $48.3 \pm 16.5$ & $21-76$ & \\
\hline \multicolumn{6}{|l|}{ Gender } \\
\hline Male & 4 & 40 & & & \\
\hline Female & 6 & 50 & & & \\
\hline Body surface area $\left(\mathrm{m}^{2}\right)$ & & & $1.8 \pm 0.1$ & & $1.4-2.2$ \\
\hline Mean disease duration until PEA (months) & & & $17.0 \pm 13.6$ & & $4-48$ \\
\hline \multicolumn{6}{|l|}{ Signs and symptoms at presentation } \\
\hline Exercise-induced dyspnea & 7 & & & & \\
\hline Angina & 3 & & & & \\
\hline \multicolumn{6}{|l|}{ New York Heart Association } \\
\hline Class II & 2 & & & & \\
\hline Class III & 5 & & & & \\
\hline Class IV & 3 & & & & \\
\hline 6-min walking test (meters) & & & $96.2 \pm 175.8$ & & $0-400$ \\
\hline $\mathrm{FEV}_{1}($ predicted \%) & & & $88.4 \pm 20.3$ & & $55-127$ \\
\hline FVC (predicted \%) & & & $86.7 \pm 18.0$ & & $60-117$ \\
\hline $\mathrm{FEV}_{1} / \mathrm{FVC}($ predicted $\%)$ & & & $80.7 \pm 10.9$ & & $58-98$ \\
\hline \multicolumn{6}{|l|}{ Pulmonary endarterectomy (mmHg) } \\
\hline Systolic & & & $79.7 \pm 36.9$ & & $23-159$ \\
\hline Mean & & & $44.2 \pm 14.4$ & & $17-65$ \\
\hline TAPSE (mm) & & & $15.8 \pm 3.7$ & & $11-22$ \\
\hline Cardiac output (1/min) & & & $3.5 \pm 1.1$ & & $2.5-5.7$ \\
\hline Preoperative PVR (dyn/s/cm-5) & & & $869.5 \pm 460.2$ & & $141-1760$ \\
\hline Cardiopulmonary bypass (min) & & & $297.4 \pm 141.7$ & & $167-454$ \\
\hline Aortic cross-clamp (min) & & & $46.9 \pm 51.3$ & & $2-161$ \\
\hline Total circulatory arrest (min) & & & $37.0 \pm 20.1$ & & $14-82$ \\
\hline
\end{tabular}

SD: Standard deviation; Min: Minimum; Max: Maximum; $\mathrm{FEV}_{1}$ : Forced expiratory volume in one second; FVC: Forced vital capacity; PAP: Pulmonary artery pressure; TAPSE: Tricuspid annular plane systolic excursion; PVR: Pulmonary vascular resistance.

hydatid cyst and one had systemic lupus erythematosus (SLE). No coagulation disorders were defined.

Conservative treatment was used in four cases and ECMO in six cases (60\%). All patients required the technique intraoperatively, either venoarterial (VA) or venovenous (VV), because of hypoxia and hemodynamic instability.

The in-hospital mortality rate was $50 \%(n=5)$. Two patients on ECMO and three patients on conservative treatment survived.

Case 1- The detailed history of the case was previously reported. ${ }^{[7]}$ Following PEA, hemorrhage from right lower lobe bronchi was observed in a 38-year-old female patient with a diagnosis of SLE. The bronchus was occluded with a Fogarty balloon catheter. A right femoral peripheral VA-ECMO was instituted. She was successfully weaned from ECMO on the fourth postoperative day (POD). On POD seven, she was weaned from ventilation and discharged on the $19^{\text {th }}$ POD.

Case 2- A 54-year-old female patient with RHC had mean pulmonary artery pressure (mPAP) of $36 \mathrm{mmHg}$ and calculated pulmonary vascular resistance (PVR) of 380 dynes/s/cm-5. Following PEA, pinky bright massive pulmonary hemorrhage $(800 \mathrm{~mL})$ was observed. Positive End Expiratory Pressure $15 \mathrm{~cm} \mathrm{H} \mathrm{H}_{2} \mathrm{O}$ was applied; phenylephrine $10 \mathrm{mg}$ and vasopressin $20 \mathrm{U}$ diluted to $10 \mathrm{~mL}$ with normal saline were administered via the endotracheal tube. The hemorrhage subsided, but soon copious amounts of pink frothy sputum suggestive of pulmonary edema appeared in the endotracheal tube. The patient was brought to the ICU requiring significant inotropic support and was ventilator dependent with reperfusion lung injury for two days. She was discharged on the $14^{\text {th }}$ POD. 
Case 3- A 21-year-old female patient with Behçet's disease and RHC had mPAP of $45 \mathrm{mmHg}$ and PVR of 977 dynes/s/cm-5. After endarterectomy was completed in the right lung, we used the technique explained above. ${ }^{[8]}$ She was weaned from CPB without any problem. She was discharged on the eighth POD.

Case 4- A 61-year-old male patient with chronic obstructive pulmonary disease and RHC had mPAP of $56 \mathrm{mmHg}$ and PVR of 977 dynes/s/cm-5. Although the operative course was uneventful, massive pulmonary hemorrhage occurred. Fiberoptic bronchoscopy showed hemorrhage from left main bronchi, which was occluded with blocker. Although a right femoral and jugular peripheral VV-ECMO was instituted, the patient died on the $10^{\text {th }}$ POD due to sepsis.

Case 5- The detailed history of the case was previously reported. ${ }^{[6]}$ A 32-year-old male patient with a history of hydatid cysts presented with PEA. Conservative treatment and physiological lung exclusion were performed. We stapled the right main PA and the right main bronchus leaving the pulmonary veins intact. On POD three, ECMO was used due to hypoxia and hypercarbia. The patient was successfully weaned from ECMO on POD seven. Unfortunately, the patient died on POD 12 due to septic shock.

Case 6- A 49-year-old female patient with RHC had mPAP of $36 \mathrm{mmHg}$ and PVR of 800 dynes $/ \mathrm{s} / \mathrm{cm}-5$. Following PEA, massive pulmonary hemorrhage was observed in right main bronchi, which was occluded and central VA-ECMO was instituted. However, the patient died on the eighth POD due to multiple organ failure.

Case 7- A 56-year-old female patient with RHC had mPAP of $32 \mathrm{mmHg}$ and PVR of 960 dynes/s/cm-5. Hemorrhage was observed in right main bronchi after PEA, which was occluded and central VA-ECMO was instituted. Unfortunately, the patient experienced multiple organ system failure and residual pulmonary hypertension refractory to pulmonary vasodilator therapy. She died on $19^{\text {th }}$ POD.

Case 8- A 61-year-old male patient with RHC had mPAP of $48 \mathrm{mmHg}$ and PVR of 896 dynes/s/cm-5. Hemorrhage was observed in right main bronchi following PEA, which was occluded and central VA-ECMO was instituted. However, the patient died on the third POD due to intracranial hemorrhage.

Case 9- A 35-year-old male patient with RHC had mPAP of $60 \mathrm{mmHg}$ and PVR of 960 dynes/s/cm-5. Hemorrhage in right main bronchi was blocked and central VA-ECMO was instituted. He was successfully weaned from ECMO on the fourth POD. On POD six, he was weaned from ventilation and discharged on the $18^{\text {th }}$ POD.

Case 10- A 76-year-old female patient with RHC had mPAP of $65 \mathrm{mmHg}$ and PVR of 1760 dynes/s/cm-5. The operative course was uneventful, but massive pulmonary hemorrhage $(1000 \mathrm{~mL})$ was observed at separation from CPB. Conservative treatment was used. She was ventilator-dependent with reperfusion lung injury for four days. She was discharged at POD 21.

\section{DISCUSSION}

This report describes a life-threatening clinical complication in a subset of patients who underwent PEA for CTEPH. A general algorithm for treatment of post-PEA hemoptysis is presented in Figure 1. Massive pulmonary hemorrhage was managed with either conservative treatment or use of ECMO depending on the origin of the hemorrhage. It is important for the operating team to be aware of this complication and the possible treatment options to salvage patients if this rare occurrence develops. Rapid decisions with a multidisciplinary team approach are mandatory for the management of massive pulmonary hemorrhage.

Pulmonary endarterectomy is a curative surgical treatment for the majority of patients with CTEPH. Although modern day operative mortality rate is 4.7 to $7 \%$, perioperative complications following PEA were reported as $49.2 \% .^{[10,11]}$ Recently, hemorrhage complications and need for ECMO have been reported as $10.2 \%$ and $3.1 \%$, respectively. ${ }^{[10,11]}$ Life-threatening pulmonary hemorrhage is a rare but potentially fatal complication with an incidence of 0.5 to $2 \% .^{[2,3]}$ It was reported that pulmonary hemorrhage is the third most common cause for perioperative mortality, with residual pulmonary hypertension and reperfusion pulmonary edema as the leading causes. ${ }^{[12]}$ It was claimed that the most important factor determining the incidence of this complication is probably the experience and skill of the surgeons. ${ }^{[2]}$ Patient risk factors for this complication are difficult to identify, although the friability of the vessels and surgical trauma bridging the PA adventitia during dissection of the endarterectomy specimen may result in massive pulmonary hemorrhage.

The management of pulmonary hemorrhage after PEA involves treatment modalities applied to pulmonary hemorrhage from other causes. Hemorrhage from intraoperative disruption of PAs usually manifests when PA blood flow is resumed at the conclusion of $\mathrm{CPB}$. The color of this hemorrhage is dark red because of venous blood in the PA. The main goals in initial 
management for massive pulmonary hemorrhage are to prevent exsanguination and ensure adequate gas exchange. If adequate hemodynamic status and gas exchange can be maintained, conservative management consisting of positive airway pressure, i.e. high PEEP, vascular occlusion with balloon inflation, topical vasoconstrictors, or embolization, pulmonary resection, reversal of heparin, and correction of coagulopathies can be provided. ${ }^{[2,4]}$ Our three of four patients were treated successfully with conservative treatment. Although physiological lung exclusion was advised as a useful salvage measure to overcome pulmonary hemorrhage, ${ }^{[13]}$ it was unsuccessful in one of our patients. ${ }^{[6]}$ Recently, Reddy et al. ${ }^{[14]}$ described a new method by temporary overnight clamping of a lobar PA to manage post-PEA pulmonary hemorrhage.

If conservative methods fail, resumption of $\mathrm{CPB}$ is indicated, and a diagnostic bronchoscopy should be performed to identify the source of hemorrhage. Lung isolation may be useful in unilateral hemorrhage, with lobar bronchial blocker used as in six of our patients.

The VV and VA-ECMO is well described for the management of reperfusion pulmonary edema following PEA. ${ }^{[15]}$ Instituting VA extracorporeal life support with active venting of the PA and the left atrium for the control of life-threatening pulmonary hemorrhage was reported. ${ }^{[4]}$ Both central and peripheral VA-ECMO have advantages and disadvantages. ${ }^{[15,16]}$ In case of severe lung injury due to diffuse hemorrhage or reperfusion lung injury, adequate oxygenation of the patient might not be possible. ECMO was used in six patients of our cohort. If a tear in PA was observed by the technique of Morsolini et al., ${ }^{[8]}$ PA was closed with a suture under circulatory arrest. We used both VA and VV-ECMO. The choice of a particular treatment depends on the site and nature of the hemorrhage, the availability of equipment and expertise, and the potential short- and long-term advantages and disadvantages. Unfortunately, only two cases on ECMO survived. The reasons for mortality were septic shock in two patients, multiple organ failure in two patients and intracranial hemorrhage in one patient.

There are some limitations to our study: (i) our small sample size of only 10 patients with endobronchial hemorrhage; and (ii) the decision to use ECMO support is subjective and bronchoscopical blocking might be equally feasible in some cases. Because of the success of this approach in a life-threatening situation, however, we have rendered this our standard procedure.
In conclusion, despite the relatively low incidence of massive pulmonary hemorrhage after pulmonary endarterectomy, it is a potentially fatal complication of surgery. Rapid decisions and early diagnosis with a multidisciplinary team approach are mandatory for the management of massive pulmonary hemorrhage. We recommend management firstly with traditional techniques when pinky bright blood appears in the endotracheal tube. On the other hand, if large amounts of bloody froth and dark blood are observed, extracorporeal membrane oxygenation support of gas exchange and hemodynamics should be considered as an adjunct to the reported management techniques.

\section{Declaration of conflicting interests}

The authors declared no conflicts of interest with respect to the authorship and/or publication of this article.

\section{Funding}

The authors received no financial support for the research and/or authorship of this article.

\section{REFERENCES}

1. Jamieson SW, Madani M. Chronic thromboembolic pulmonary hypertension. Ann Vasc Dis 2009;2:133-5.

2. Manecke GR Jr, Kotzur A, Atkins G, Fedullo PF, Auger WR, Kapelanski DP, et al. Massive pulmonary hemorrhage after pulmonary thromboendarterectomy. Anesth Analg 2004;99:672-5.

3. Daily PO, Dembitzsky WP, Iversen S, Moser KM, Auger W. Current early results of pulmonary thromboendarterectomy for chronic pulmonary embolism. Eur J Cardiothorac Surg 1990;4:117-21.

4. Pretorius V, Alayadhi W, Modry D. Extracorporeal life support for the control of life-threatening pulmonary hemorrhage. Ann Thorac Surg 2009;88:649-50.

5. Yıldızeli B, Taş S, Yanartaş M, Kaymaz C, Mutlu B, Karakurt S, et al. Pulmonary endarterectomy for chronic thrombo-embolic pulmonary hypertension: an institutional experience. Eur J Cardiothorac Surg 2013;44:219-27.

6. Bakan S, Kandemirli S, Yıldırım O, Ersen E, Yanartaş M, Taşçı E, et al. Hydatid cysts of the pulmonary artery. Turk Gogus Kalp Dama 2016;24;592-5.

7. Yıldızeli B, Arslan Ö, Taş S, Eldem B, Aksoy E, Koçak $\mathrm{T}$, et al. Management of massive pulmonary hemorrhage following pulmonary endarterectomy. Thorac Cardiovasc Surg 2014;62:89-91.

8. Morsolini M, Azzaretti A, Orlandoni G, D’Armini AM. Airway bleeding during pulmonary endarterectomy: the "bubbles" technique. J Thorac Cardiovasc Surg 2013;145:1409-10.

9. Yıldızeli ŞO, Yanartaş M, Taş S, Direskeneli H, Mutlu B, Ceyhan B, et al. Outcomes of patients with Behçet's Syndrome after pulmonary endarterectomy. Thorac Cardiovasc Surg 2018;66:187-92. 
10. Mayer E, Jenkins D, Lindner J, D’Armini A, Kloek J, Meyns B, et al. Surgical management and outcome of patients with chronic thromboembolic pulmonary hypertension: results from an international prospective registry. $\mathrm{J}$ Thorac Cardiovasc Surg 2011;141:702-10.

11. Pepke-Zaba J, Delcroix M, Lang I, Mayer E, Jansa P, Ambroz D, et al. Chronic thromboembolic pulmonary hypertension (CTEPH): results from an international prospective registry. Circulation 2011;124:1973-81.

12. Jamieson SW, Kapelanski DP, Sakakibara N, Manecke GR, Thistlethwaite PA, Kerr KM, et al. Pulmonary endarterectomy: experience and lessons learned in 1,500 cases. Ann Thorac Surg 2003;76:1457-62.

13. Metin M, Toker A, Sayar A, Gürses A. Physiological exclusion for massive hemoptysis: when? Eur J Cardiothorac Surg 2001;20:1065-6.

14. Reddy S, Rajanbabu BB, Kumar NK, Rajani I. Temporary clamping of branch pulmonary artery for pulmonary hemorrhage after endarterectomy. Ann Thorac Surg 2013;96:1459-61.

15. Berman M, Tsui S, Vuylsteke A, Snell A, Colah S, Latimer $\mathrm{R}$, et al. Successful extracorporeal membrane oxygenation support after pulmonary thromboendarterectomy. Ann Thorac Surg 2008;86:1261-7.

16. Thistlethwaite PA, Madani MM, Kemp AD, Hartley M, Auger WR, Jamieson SW. Venovenous extracorporeal life support after pulmonary endarterectomy: indications, techniques, and outcomes. Ann Thorac Surg 2006;82:2139-45. 